\title{
WINDOW TO THE WEST
}

\author{
MEMORIES OF WATCHING FINNISH \\ TELEVISION IN ESTONIA DURING THE \\ SOVIET PERIOD
}

Annika Lepp

Estonian Society for the Protection of Animals Mardi 11, 10113 Tallinn

Estonia

annika.lepp@loomakaitse.ee

Mervi Pantti

Department of Social Research, Media and Communication Studies

Unioninkatu 37

PL 54

00014 University of Helsinki, Finland

mervi.pantti@helsinki.fi

\begin{abstract}
This study is concerned with the memories that Estonians have of watching Finnish television during the last decades of the Soviet occupation. We will look at the practices of watching Finnish television in Soviet Estonia and the meanings attributed to it. Finnish television took North-Estonians into a colourful world of consumption and entertainment, while educating them about Western values and encouraging them to dream of a better future. We identify four ways that North-Estonians remember Finnish television (and its programmes): as an event, as a means of distinction, as a window to a world of affluence, and as a tool of democratic education.
\end{abstract}

Keywords: Television memories, Finnish television, Estonian television viewers, transnational television

In 1971, the Finnish Broadcasting Company (YLE) built a new TV-mast in Espoo. This TV-mast unintentionally transmitted Finnish TV broadcasts to northern Estonia and as a result, watching Finnish television became a part of everyday television consumption in Northern Estonia during the last decades of Soviet occupation. Despite many efforts made by the Soviet authorities to restrict access to the 'ideologically and morally harmful' TV broadcasts that were making their way across the Gulf of Finland, ${ }^{1}$ Finnish television attracted larger audiences than the programming of Soviet Central Television from Moscow. ${ }^{2}$ 
Estimations about the viewing figures and popularity of Finnish broadcasts in the Soviet period differ. According to Hagi Šein, from 1974 to 1979, the average weekly consumption of Finnish television among Estonian residents was close to thirteen percent, compared to five percent for Moscow's central television. ${ }^{3}$ Between 1970 and 1990, six television channels were available in Estonia: ETV, Soviet Central Television I, Soviet Central Television II, Leningrad TV and the Finnish YLE 1 and 2. In 1991, the year when Estonia regained its independence, the most watched television broadcaster among the Estonian-speaking audience was Estonian national television (ETV), while Finnish television channels were the second most popular choice. ${ }^{4}$

The cross-border watching of 'bourgeois' television was not uncommon in the border areas of the former Eastern bloc. For example, most East Germans regularly tuned in to West German broadcasts. ${ }^{5}$ Watching Finnish television was not the only transnational media practice in Estonia and before the television spillover from Finland began, Radio Liberty was the main window to the West. However, while the broadcasts of Radio Liberty were regularly interrupted by Soviet radio transmitters, ${ }^{6}$ Finnish television was a medium that the Soviet censor was not able to block.

The role of Finnish television in facilitating the transition towards democracy in Estonia at the beginning of the 1990s has been discussed in both popular and official discourses in Estonia. Finnish television has been credited as a key agent of change because it exposed Estonians to Western values and served as a tool for the Estonian subversion of communist power. For instance, when speaking about Estonia's EU membership, its current President Toomas Hendrik Ilves, wrote:

From the 1960s, Finland represented Estonia's window to the West: we watched Finnish television, saw things such as democratic elections (!), realised that Lech Walesa had a moustache (his picture was forbidden), and from bad American television shows like Dallas we came to believe that people in the West lived like JR. ${ }^{7}$

We aim to examine how this 'window to the West' is experienced and remembered by Estonians. Our aim is to contribute to the limited body of audience studies within the scholarly field of media and memory: first, by departing from the national television paradigm and looking at transnational television memories, and, second, by looking at the 'memory work', ${ }^{8}$ the reconstruction of the past through narrating the television memories of people who lived under a communist regime. We highlight the importance of the socio-political context to the ways in which television is remembered. Obviously, Finnish television programmes did not have the same meanings for Estonian and Finnish audiences because the meanings of Finnish television for Estonians were shaped in relation to the conflict between the Soviet ideology and everyday life.

\section{Remembering Finnish Television}

Collective memory is necessarily 'socially framed': individual memories cannot be separated from the memory of a social group. ${ }^{9}$ It also necessarily includes a narrative of the past. Existing literature on media and memory mainly focuses on the role of media texts in constructing the past. ${ }^{10}$ Our focus here is on how Estonians remember Finnish television, and how the past is constructed through these memories. However, it is important to keep in mind that

3 Šein, 2004, p. 95

4 Šein, 2005, p. 176

5 Holger Lutz Kern and Jens Hainmueller, "Opium for the Masses: How Foreign Media can Stabilize Authoritarian Regimes”, Political Analysis, 17, 4, 2009, p. 377-399; Michael Meyen and Katja Schwer, "Credibility of Media Offerings in Centrally Controlled Media Systems. A Qualitative Study Based on the Example of East Germany," Media, Culture \& Society, 29, 2007, p/ 285-304. Dana Mustata has studied cross-border television in Romania. See Dana Mustata, "Within Excess Times and a Deficit Space: Cross-border Television as a Transnational Phenomenon in 1980s Romania", in Andreas Fickers and Catherine Johnson, eds., Transnational Television History: A Comparative European Approach, Routledge, 2012.

6 SL Õhtuleht, "Raadiohääli segati Kuibõševist", Õhtuleht, 16.06.2001, htttp://www.ohtuleht.ee/107853, 17 May 2013

7 Toomas Hendrik Ilves, 'Some kind of Solution: Estonia, Finland and the Enlargement. "No longer a poor cousin awed,"' Helsingin Sanomat ,1 May 2004 http://www.hs.fi/english/article/Some+kind+of +Solution+Estonia+Finland+and+the+Enlargement/1076152642289, 17 May 2013

8 Annette Kuhn, An Everyday Magic: Cinema and Cultural Memory, I. B. Tauris, 2002

9 Maurice Halbwachs, On Collective Memory, Harper Colophon Books, 1992 [1925]

10 Motti Neiger, Oren Meyers and Eyal Zandberg, On Media Memory: Collective Memory in a New Media Age, Palgrave Macmillan, 2011 
since memory is a social process, it is constantly reconstructed depending on the situation in which the events are recalled. ${ }^{11}$

To provide an understanding of the relationship between watching Finnish television and the socio-political context, we collected 'themed life-stories'. ${ }^{12}$ This was done through written memories and oral interviews. Participants were recruited in October 2010 through an advertisement that was published in the print and online edition of Tallinn's free weekly newspaper Linnaleht. They were also recruited through the webpage of the study, which was publicized through e-mail, Facebook and Twitter. Furthermore, the study was promoted on a national radio channel (Raadio 2) during the radio programme Siin Me Oleme. The advertisement and the webpage included a set of questions designed to elicit personal stories about watching Finnish television. The questions were: what meanings did Finnish television have in your everyday life during the Soviet time? Which programmes did you watch and why? How do you perceive the influences of Finnish television broadcasts on your life?

The only selection criteria for the participants were that they were born before 1975 (over 16 when the Soviet regime collapsed in 1991) and were Estonian-speaking (Estonian and Finnish belong to the same group of Finnic languages - while the languages are not mutually intelligible, the relationship between the two helps the learning process). The Russian-speaking minority was not included in the study because Finnish television was assumed to be less popular among the Russian minority. Finnish television also reached the Soviet Karelia (Vyborg) region, but it was not widely viewed in the border area because of language difficulties..$^{13}$ Accordingly, Soviet Central Television was the most watched channel among the Russian-speaking audience in Estonia in 1991, while Finnish television was the least watched type of programming among them. ${ }^{14}$

The data includes 83 written responses and 5 oral history interviews that were conducted with three men and two women in 2011. The age of the interviewees was: 42, 35, 75, 49 and 69. The average age of all respondents was 38 (69 being the oldest, 24 the youngest), $66 \%$ of the respondents were females and $34 \%$ males. As supporting data, we used 17 anonymous written memories collected by ETV in October 2006 for the documentary film Disco and Atomic War (Disko ja tuumasõda, 2009) done by Jaak Kilmi and Kiur Aarma. ETV invited Estonians to write about their most memorable or funniest experiences with Finnish television during the Soviet regime. Both the interview transcriptions and written responses were coded by themes and keywords.

11 Emily Keightley, Engaging with Memory, in Michael Pickering, eds., Research Methods for Cultural Studies, Edinburgh University Press, 2008

12 Jérôme Bourdon, "Media Remembering: The Contributions of Life-Story Methodology to Memory/Media Research," in Motti Neiger, Oren Meyers and Eyal Zandberg, eds., On Media Memory:

Collective Memory in a New Media Age, Palgrave Macmillan, 2011, p. 63.

13 Lauristin, 1997

14 Šein, 2005, p. 177 


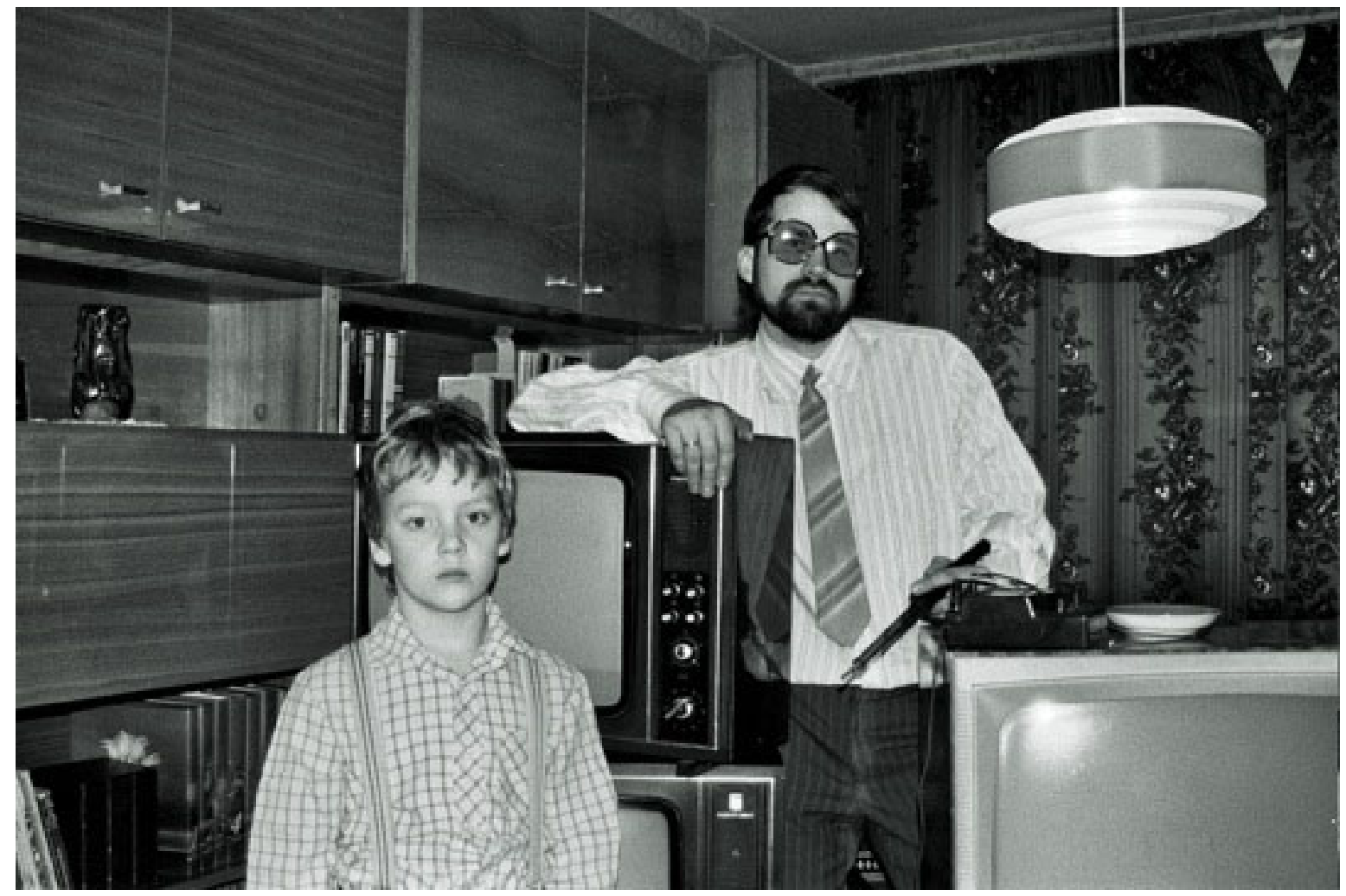

Fig.1 Disco and Atomic War documentary investigates the role of the Western popular culture that came through Finnish TV in Estonia in the 1970s and 1980s. Source: Jaak Kilmi

\section{Finnish Television As An Event}

Jérôme Bourdon writes that 'remembering television' is not synonymous with remembering viewing specific programmes. ${ }^{15}$ While many programmes stand out as memorable, the memories of watching Finnish television are often connected to the world outside television. While viewing Finnish television during the Soviet time was remembered as a 'normal' or 'compulsory' part of everyday life, it was also connected with eventful memories.

The eventfulness emerged through the organization of viewers' lives around the Finnish television schedules, rather than the schedules of Estonian television or the Soviet Central Television. It is important to note that Estonia was in Moscow's time zone during the decades of the Soviet regime. Although Tallinn is located only $80 \mathrm{~km}$ south of Helsinki, Estonian time was one hour ahead of Finnish time. For young viewers, living according to the Moscow time involved painstaking negotiations with parents who were opposed to late night television viewing.

As a child, you often had to put in extra effort to convince your parents to allow you to watch the evening programmes, which, according to Moscow's time, started very late, especially if it was a school night. (Põhjaeestlane, age and gender unknown) 
well as to the associated yearning for watching Finnish television programmes. Chasing opportunities to watch Finnish programmes, as well as chasing television signals, are central aspects of these memories. Given that the signals of Finnish television could be received only in northern Estonia, many respondents talked about efforts to build special antennas and television blocks that could catch at least a fraction of the TV-signal. ${ }^{16} \mathrm{As}$ a result, people with technical skills were highly valued in the central and southern parts of Estonia.

Every workshop of a kolkhoz had at least one technician who was able to construct so-called 'Finnish blocks', for a certain fee of course... They also built the necessary outdoor antennas, one of which is still standing on the roof of a private house in Türi [a town about $100 \mathrm{~km}$ from Tallinn]. (Juhan, 47, male)

'Television tourism', travelling to the North coast to watch Finnish television programmes became common practice. If the signal could not be received at home, people had to go to places that had reception of Finnish TV signal:

Me and my parents lived in Viljandi County. But my sister lived in Tallinn. ... On most weekends I would take the train from Viljandi to Tallinn to watch my favourite series. When Finnish television started to air the series of Emmanuelle, my parents soon headed to Tallinn as well. Back then, the Tallinn-Tartu highway was crowded with fans of Finnish programming, or the television tourists as I would call them. (Kristel, 40, female)

The Finnish television that Estonians watched during the periods of stagnation and Perestroika were very different from today's multi-channel television. Until 1993, Finnish television consisted of two public channels, TV1 and TV2. YLE had no right to air advertisements - that right was given to a private company MTV, which operated by YLE's legal franchise and leased airtime on YLE's channels (until 1993 when MTV got its own operating license and channel, MTV3). MTV provided popular entertainment, such as the American prime time television soap opera Dallas, while YLE offered a broader assortment of information, 'quality entertainment' and educational programmes.

How well do Estonians remember Finnish television programmes? Participants' memories show strong similarities regarding specific programmes and viewing habits. However, 248 unique mentions of Finnish programmes also demonstrate the plurality of the viewing practices. Moreover, while some participants vividly recount their experiences, some had problems recalling anything specific. Some respondents recalled only certain types of programmes (e.g. Westerns or music shows).

The most frequently remembered programme was Knight Rider, an American television series, followed by TV1 news and TV2's children's magazine Pikku Kakkonen ('Little Two'). MTV aired Knight Rider from 1984 to 1987, and most of the participants were in their teens when the show was broadcast. Thus, it is no wonder that a series with a hightech hero (David Hasselhoff) and a talking car would win the hearts of young Estonians. A cross-cutting theme in the interviews and written responses was the discussion of the content of Finnish television in schools and the games that it inspired. The next most popular programmes were the worldwide hit shows Dallas, Emmanuelle, MacGyver and Dynasty. Also, some people who claim to have never watched these shows, recall them as 'the most important programmes' in Finnish television.

Finnish television was an important source of popular culture for the Soviet Estonians. All media content was censored in the Soviet Union in order to create an 'ideologically correct symbolic environment' and to ensure that the media functions as an ideological tool of the Communist Party. ${ }^{17}$ For the respondents, it was thrilling to see films without the communist rhetoric. In particular, American Western and crime films were watched with a great deal of yearning for a world with different values and ideology. Given that Western pop music was forbidden in the Soviet Union, it was no wonder that a programme such as the Eurovision Song Contest was fondly remembered. The biggest media event, however, was the broadcasting of the French soft-core porn film series Emmanuelle in the summer of 1987. Sex was among the topics that could not be mentioned publicly in the Soviet Union, and these series seemed to be earthshattering for Estonian adults and children.

16 Similar practices were occurring in other Eastern Bloc countries. See Dana Mustata, "Within Excess Times and a Deficit Space: Cross-border Television as a Transnational Phenomenon in 1980s Romania", in Andreas Fickers and Catherine Johnson, eds., Transnational Television History: A Comparative European Approach, Routledge, 2012

17 Karol Jakubowicz, "Media as Agents of Change," in D.L. Paletz, K. Jakubowicz, P. Novosel, eds., Glasnost and After. Media and Change in Central and Eastern Europe, Hampton Press, p. 23. 


\section{The Television Of Distinction}

The second type of memories is related to the ways in which Finnish television created a divide between those who were able to watch Finnish programmes and those who were not. These memories of distinction are based on different kinds of gains or advantages that come from watching Finnish television. It became clear in the interviews and written stories that watching Finnish television was about gaining cultural capital that gave some people a better chance at success in life.

Cultural capital is formed by knowledge, skills and experiences. ${ }^{18}$ The most frequently mentioned benefit of watching Finnish television was learning the Finnish language. This was obviously important in order to be able to follow Finnish television programmes, but learning Finnish was also economically, socially and culturally beneficial for people's future lives.

I learned Finnish from Finnish television. ... I even managed to do some business with the Finns in the late 1980s. ... I am very grateful to have lived in Tallinn and to have been able to see Finnish television. The latter was the basis of my Finnish language skills, which I acquired without any help from schools or courses, and which allowed me later to become a project manager at a translation bureau and have Finnish companies as clients. (Urme, 39, female)

While the generation that grew up with MTV usually speaks three foreign languages - Finnish, English and Russian [learning Russian was obligatory during the Soviet time], those who grew up with local television alone speak only Russian. (Põhjaeestlane, age and gender unknown)

Finnish-Estonian dictionaries were acquired with the hope of being able to understand Finnish programmes better. However, not all people who had access to Finnish television were able to learn the language. This seems to be a generational issue: some older participants talked about their difficulties in learning Finnish and some young participants confirmed that their parents never learnt it.

In the context of the Soviet Union's economic shortages, linguistic, technical and other skills learned through Finnish television could be economically useful. Private entrepreneurship was illegal in the Soviet Union, but this did not prevent black-market activities, targeted at helping people receive Finnish television, from flourishing. Thus, people with technical skills moonlighted by providing illegal TV installation and reception equipment services against payment. The expensive but highly popular units that received the audio and colour signals of Finnish television were called 'blocks', and without them Estonians could only receive mute, black-and-white pictures.

I think that the block cost about 50 roubles. It was a rather high price, considering that the average salary back then was around 120 roubles. ... Our block-guy wore a Finnish pipo [a wool beanie hat] so I suppose he must have earned quite well from all those blocks. (Peeter, 42, male)

Finnish television could be monetized in many other ways. People copied Finnish TV guides and recorded music from Finnish television sets by simply holding a recorder or a microphone next to the screen. Cassettes full of music recorded from Finnish television were played at different events. Another popular activity was taking photographs of television screens, capturing precious images of for example, Western actors and bands, and selling the photos in schools. 


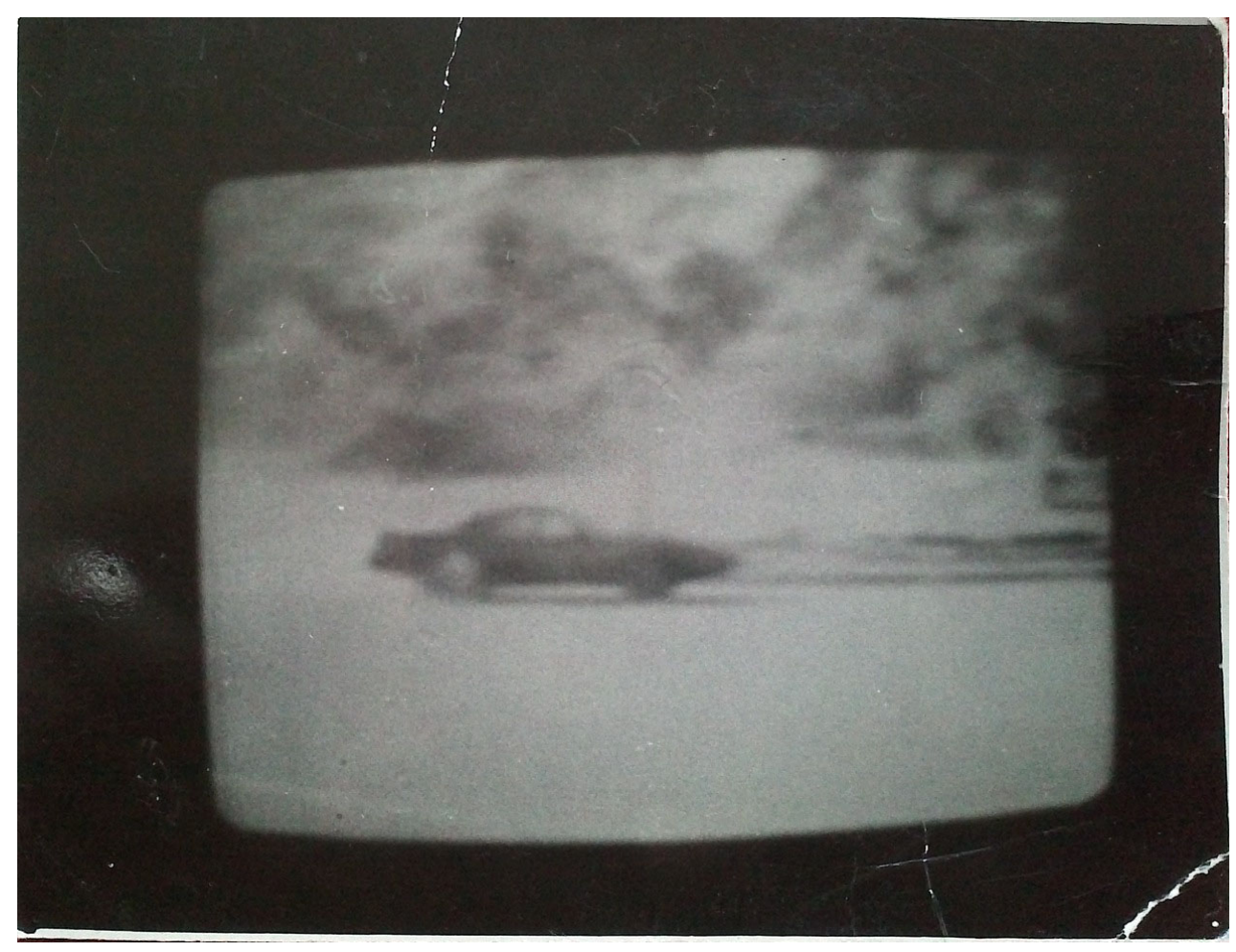

Fig. 2 The super car K.I.T.T. from Knightrider. Source: Raimo Jussila.

Clearly, one of the key words mentioned in the viewers' recollections was 'advantage': the participants saw themselves as superior - in terms of political awareness - to the Estonians who were unable to watch Finnish television. Those who were not able to watch Finnish television were easily labelled as uneducated 'hillbillies'. This feeling, common among the young participants, was not shared by the older generation who was born at the time of Estonia's first period of independence (1918-1940). These respondents did not feel that Finnish television was a political educator to the same extent that the younger generation did.

The younger generation of Estonians believed that the experience of watching Finnish television during the Soviet occupation made them more aware of the world outside, and offered them knowledge about the democratic form of government, free speech and the market economy. A sense of superiority and control was also felt over the Soviet rule. One of the participants described this feeling through his experience of watching the Olympics in 1984:

I remember the emotional moments of the opening ceremony of the Los Angeles Olympics. The Russians boycotted the games. But we watched Finnish television. This situation made it even more interesting and exciting: forbidden games, but we were watching. Due to the time difference, the broadcast was late at night. When the ceremony ended, the sun went down behind the stadium. The camera was filming the moment... and at that point, when I went out on the porch, the sun just started to rise from behind the sea. It was exhilarating. It was the same sun that just went down in America. The same moment of time, the same Earth, but just another country. The feeling was special. I had a feeling of superiority over this Soviet country, and its rulers. (Anonymous) 


\section{Window To A World Of Affluence}

The third type of memories centres on the alternative reality offered by Finnish television programmes. During the Soviet time, the standards of living in Estonia were poor compared to its Western neighbour, and Estonians became increasingly aware of this through Finnish television. Finland had long been an ideal 'alter ego' for Estonians, but during the Soviet rule the interest intensified as Finland became 'proof of what Estonia would have been if the country had not ended up under the Soviet occupation'.19

With the popularity of Finnish television, a general admiration of Finland and the Finns developed in Estonia. The desire to visit Finland and have a Finnish friend was often described. During sports events that aired on Finnish television, Soviet Estonian audiences crossed their fingers for the Finnish teams and athletes. The expression 'domesticated Finn' ('kodustatud soomlane') stood for a Finnish person who visited her Estonian acquaintances and brought them the desired Western goods from Finland. These Finns also gave Estonians the chance to practice their television-learned Finnish.

For the Estonian viewers, Finnish television represented a world of affluence, beauty and colours. Indeed, colours seem to have a central place in participant's memories. They often pointed out that the colours on Finnish television were bright, fresh and vivid, while the colours on Estonian and Soviet Central Television were 'brown and depressing', just like they were in the real life of scarcity.

I started using the expression 'Finnish green', which meant a colour of green that is bright and clean, and that was to be seen only on Finnish television. (Hanna, 30, female)

Bright colours were remembered in particular with regards to Finnish food advertisements. During the last decade of the Soviet Union, in the period of Perestroika, stores were almost empty and people stood in lines for hours to buy bread and milk. Some participants discussed the rumours that the food in Finnish commercials was not real and that the food items were merely props.

Those colourful clothes, shampoos and big red chunks of meat! ... Our neighbour told us that such things do not actually exist - they are probably just plastic decorations. (Maris, 32, female) 


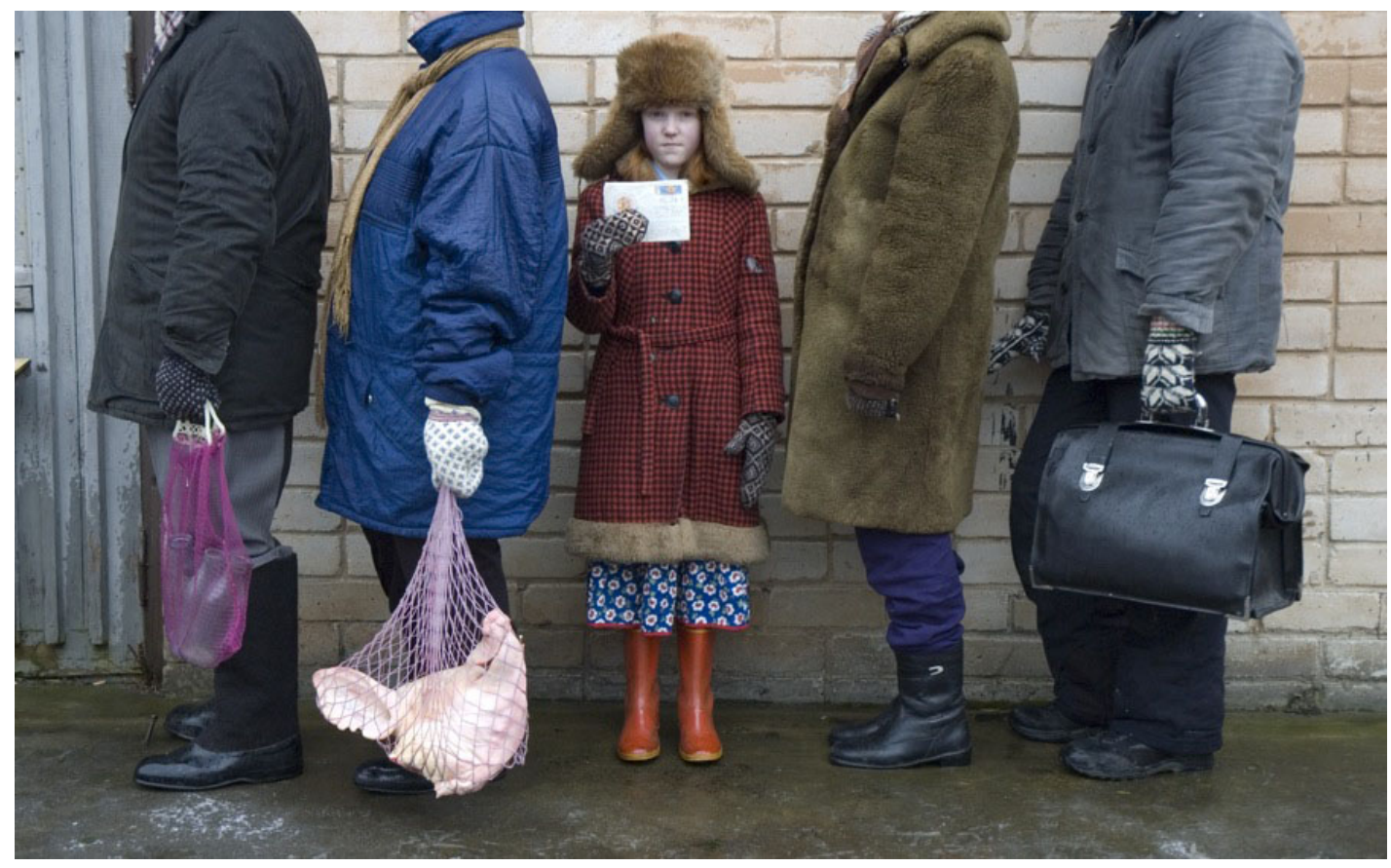

Fig. 3 A still photo from Disco and Atomic War. Source: Jaak Kilmi

Estonians were introduced to consumerism through Finnish television. Female viewers talked about how a strong desire for fashionable clothes, interior decoration, hairstyles and make-up was fuelled by Dallas and other American prime-time shows. Not surprisingly, commercials were some of the most frequently recalled content from Finnish television. People remember singing the tunes of Finnish commercials and dreaming of the advertised products.

The first thing that comes to my mind when thinking about my childhood is ads seen on Finnish television. The most vivid memories are of Jenkki chewing gum, all those liquorices, Tupla and Dumle chocolate commercials. It felt like heaven: somewhere there is actually a country where all this stuff can be bought in stores. (Taimi, 35, female)

\section{Video 1. Indiana Jones - inspired the 1988 Tupla commercial}

However, the longing for goods was most common among the younger generations that had watched Finnish television from an early age. Older participants were not taken by Finnish television commercials in the same way that the younger generation was. A 69-year-old Merike, a former museum director, noted that the myriad of colourful products in Finnish commercials was seen more as a fact of life:

I just knew that's the way things were: we lived here in our poor economy and under socialism. Under this socialism, everything was grey and feeble. Nobody actually died of hunger but nobody got anything more either. That was it. My friends and I were more concerned about the 'curtain' that covered up culture and information. 


\section{Education For Democracy}

The view that transnational flows of communication played a major role at the end of the ommunist period is widespread. Kern and Hainmueller, ${ }^{20}$ however, claim that in East Germany, West German television helped to stabilize rather than undermine the communist rule. Without a doubt, Finnish television, with its popular series and programmes, offered an escape from the grey socialist reality, an escape that is still passionately remembered, but which also fostered dissatisfaction.

The Soviet state had a monopoly on information, meaning that all information was ideologically controlled. This was particularly true during the period of stagnation (until 1985), when Moscow strictly dictated what could and could not be aired on television. ${ }^{21}$ For the respondents, Finnish newscasts provided the only reliable source of information. In the beginning of Perestroika, Finnish television news was more popular than the news on Estonian television. In 1985, the evening news from Estonian public television was viewed by 77000 residents of Tallinn, whereby the number of viewers for the Finnish television evening news in Tallinn was $180000 .{ }^{22}$

Respondents remembered several news events that were of pivotal importance for their 'political education' and their dissatisfaction with the Soviet rule. On Soviet television, news about the Prague Spring, the Polish Solidarity Movement, the Soviet attack on a Korean civilian airliner, the Chernobyl disaster, the Soviet submarine running aground in Swedish territorial waters and the deaths of Alexei Kosygin and Leonid Brezhnev, were all either censored, publicized too late, or not at all.

One of the interviewees vividly described how Finnish television news provoked a spirit of protest inside her. The more she saw and heard about the outside world that contradicted the official Soviet narrative, the angrier she became about life in the Soviet society.

When I saw the news on Finnish television, and they hardly ever coincided with the information spread in Aktuaalne Kaamera [an Estonian news programme] and Vremja [a news programme of the Soviet Central Television], the lies and the hypocrisy just got me mad. It was clearly a source of frustration that developed into a frantic spirit of protest. I knew that my brain could no longer be washed - I had a basis for comparison. I raged inside as I knew that the world, which is shown on Finnish television, actually exists. My anger towards the Russians was immense. And the more I watched Finnish television, the bigger it grew. (Kai, 56, female)

Most respondents mentioned that the Soviet propaganda did not work on them because of Finnish television, which had helped them to develop their own opinions about the world around them.

I would not have believed the Soviet propaganda even without Finnish television. Neither would my friends in South-Estonia. But Finnish television created a sort of a 'translation mechanism' that helped us read the Soviet media between the lines. I believe that all thinking Estonians knew how to do that, but it was probably easier for those who watched Finnish television. (Anonymous, 60, male)

\section{Conclusion}

The urgent desire to watch Finnish television began to decline significantly after the collapse of the Soviet Union in 1991 because Estonians had more alternatives to satisfy their need for information and entertainment. By examining shared themes in the memories collected, we can say that watching Finnish television in the Soviet time was appropriated in many different ways by Soviet Estonians. Broadcast spillovers from Finland created a more

20 Kern and Hainmueller, 2009, p. 393

21 Epp Lauk and Svennik Høyer, "Recreating Journalism after Censorship: Generational Shifts and Professional Ambiguities among Journalists after Changes in the Political Systems," Central European Journal of Communication, 1, 1, 2008.

22 Mati Graf and Heikki Roiko-Jokela, Vaarallinen Suomi: Suomi Eestin kommunistisen puolueen ja Neuvosto-Viron KGB:n silmin, Minerva, 2004, p. 176. 
transnational communication space, which was seen as pivotal for undermining the Soviet rule. However, in addition to connecting Estonians to democratic values, Finnish television, importantly, was seen as an educator for the market economy. Of no less importance was the way that Finnish television watching was seen to have made a difference in their personal and professional lives by giving them advantages - such as learning Finnish - by comparison to those who did not watch Finnish television. This study confirms the increasingly expressed need to pay more attention to the transnational television history of Europe, both from behind the Iron Curtain and before the emergence of commercial television. ${ }^{23}$

Television programmes, as Mari Pajala has stated, create memories and interpretations from the past and from the people. ${ }^{24}$ The study has shown that for the most part, the viewers of Finnish television in Estonia share common memories about their experiences with Finnish television during the Soviet occupation. When this study was started, the documentary film Disco and Atomic War had already been aired and it was followed by an enthusiastic discussion in the Estonian media. The material studied here also includes written responses that were collected in 2006 by ETV as a source for the documentary. The responses written both prior to and after the documentary were very similar. Still, many of the respondents that discussed their memories in 2010 mentioned the film and it is very likely that it had at least refreshed their memories. It is important to note that most of the participants were still children during the Soviet period and their shared reminiscences of the influence of Finnish television on their personal and political lives are influenced by - as well as creating - their present selves in free Estonia.

Finally, it is important to note that this shared cultural memory seems to be generational. While those who were children or young adults during the last two decades of the Soviet rule have very similar memories, especially concerning entertainment, the older generation who were born at the time of Estonia's first period of independence (1918-1940) or whose parents clearly remembered this time period, seemed to remember their relationship with Finnish television less affectionately. For them, unlike for the younger generation who did not have any personal experiences with democracy and who grew up with Finnish television, Finnish programmes did not appear as a window to the democratic form of governance, capitalist values, consumerist dreams, or as a popular cultural heaven. For the older generation, Finnish television portrayed a vision of how Estonia could have developed without the Soviet occupation.

\section{B i o graph y}

Annika Lepp is a Communication Manager in the Estonian Society for the Protection of Animals. Previously she has worked as a PR consultant at the communication agency $\mathrm{H}+\mathrm{K}$ Strategies and as Executive Manager and Member of the Board of a media monitoring and analysis company Meedius Eesti OÜ. She graduated with a MSSc degree in Media and Global Communication from the University of Helsinki in 2012.

Mervi Pantti is Associate Professor and Director of the International Master's Programme in Media and Global Communication in the Department of Social Research, Media and Communication Studies, at the University of Helsinki. She has published on mediated emotions, crisis reporting and popular television. Her latest books are Amateur Images and Global News (Intellect, 2011, with Kari Andén-Papadopolos) and Disasters and the Media (Peter Lang, 2012, with Karin Wahl-Jorgensen and Simon Cottle).

23 See e.g. Andreas Fickers, Catherine Johnson, eds., Transnational Television History: A Comparative Approach, Routledge, 2012.

24 Mari Pajala, "Making Television Historical: Cultural Memory of the Eurovision Song Contest in the Finnish Media 1961-2005", Media History, 17, 4, 2011, p. 405-418

VIEW Journal of European Television History and Culture Vol. 1, 3, 2013 Article ID: jethc034 | URL: http://www.viewiournal.eu Publisher: Netherlands Institute for Sound and Vision in collaboration with Utrecht University, Maastricht University and Royal Holloway University of London. Copyright: The text of this article has been published under a Creative Commons Attribution-Noncommercial-No Derivative Works 3.0 Netherlands License. This license does not apply to the media referenced in the article, which is subject to the individual rights owner's terms. 